Supplement of Nat. Hazards Earth Syst. Sci., 18, 3037-3043, 2018

https://doi.org/10.5194/nhess-18-3037-2018-supplement

(c) Author(s) 2018. This work is distributed under

the Creative Commons Attribution 4.0 License.

(c) (1)

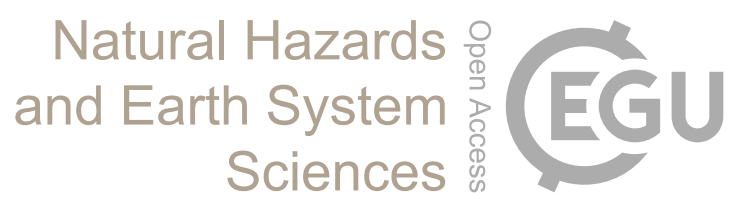

Supplement of

\title{
Brief communication: Meteorological and climatological conditions associated with the 9 January 2018 post-fire debris flows in Montecito and Carpinteria, California, USA
}

Nina S. Oakley et al.

Correspondence to: Nina S. Oakley (nina.oakley@dri.edu)

The copyright of individual parts of the supplement might differ from the CC BY 4.0 License. 
Supplemental Material

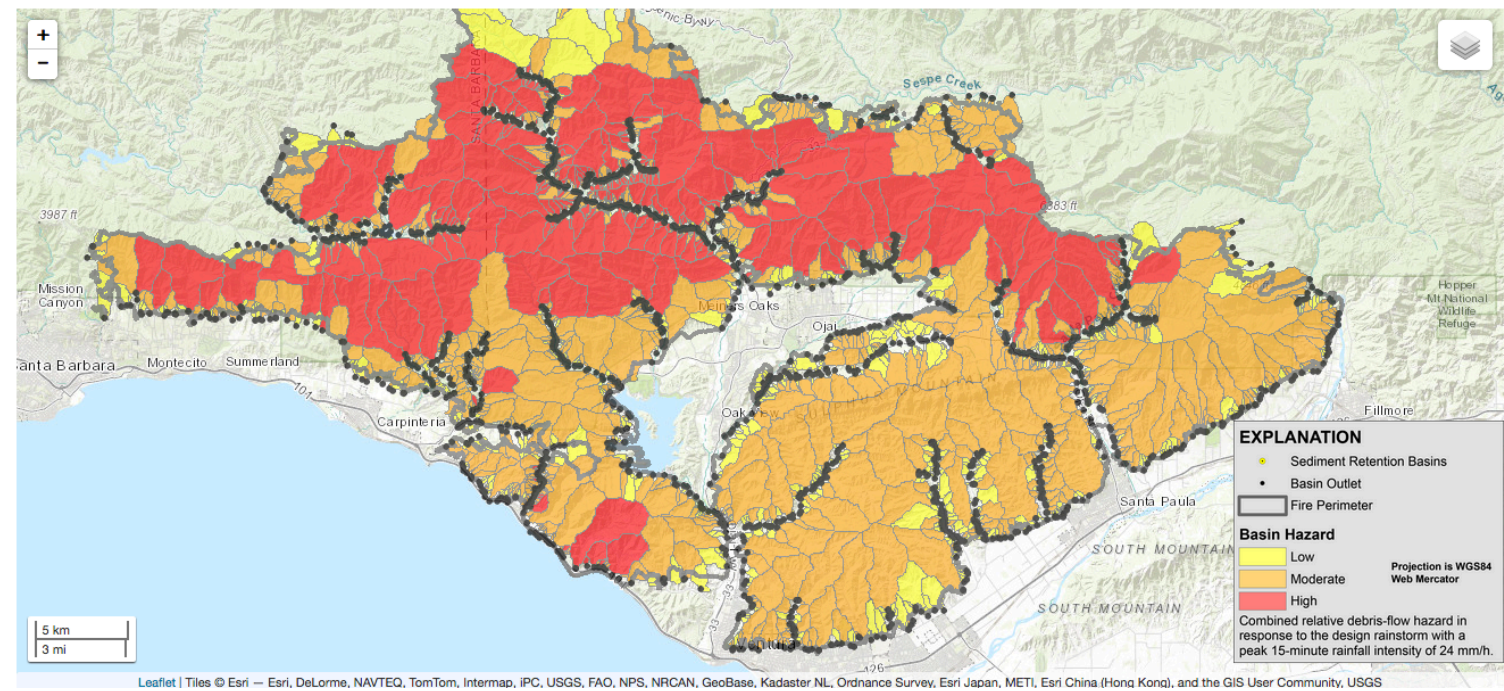

Figure S1: USGS map of debris flow hazard by basin for the Thomas Fire burn area. This map can be accessed at:

https://landslides.usgs.gov/hazards/postfire_debrisflow/detail.php?objectid=178 


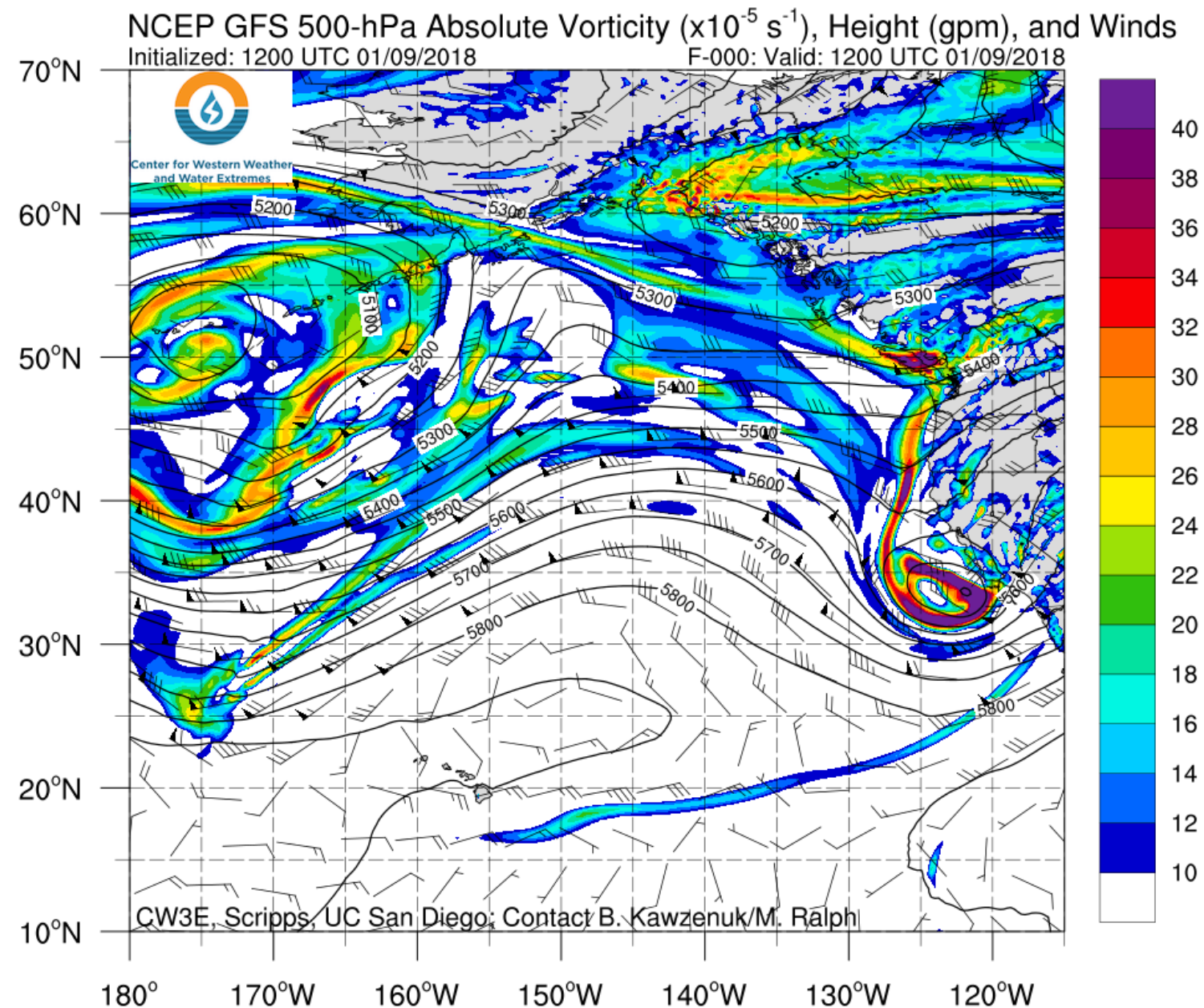

Figure S2: Absolute vorticity field (filled contours) from the National Centers for Environmental Prediction Global Forecast System. The time step shown is the 00 hour forecast for 12 UTC, the available model time closest to the actual time of the event (11:30-11:45 UTC). Note area of enhanced vorticity (dark red) rotating into Southern California area. The height field at $500 \mathrm{hPa}$ is also displayed, note closed low pressure system situated at $34^{\circ} \mathrm{N}, 122^{\circ} \mathrm{W}$. 


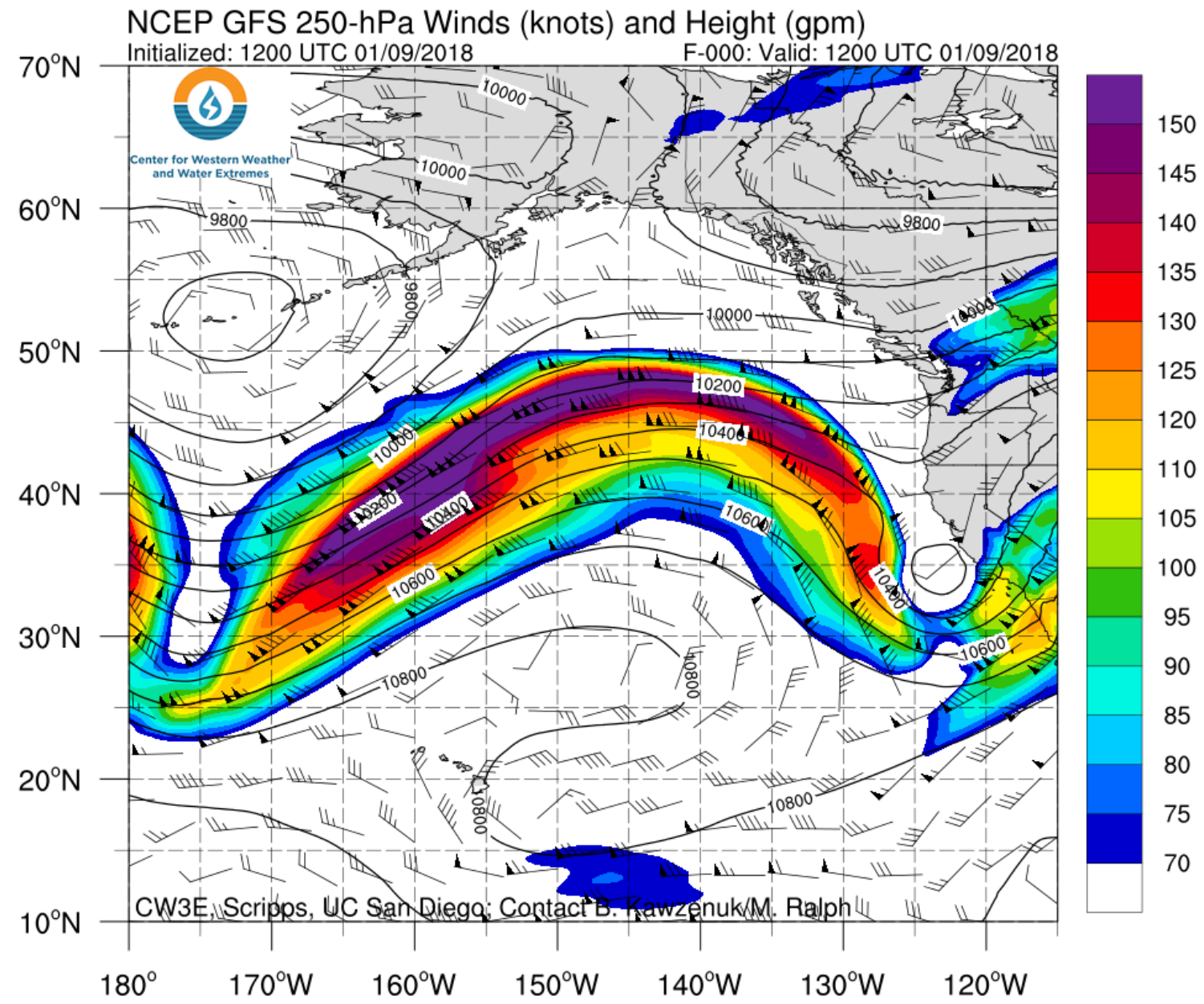

Figure S3: Wind barbs and speed (filled contour) at $250 \mathrm{hPa}$ from the National Centers for Environmental Prediction Global Forecast System. The time step shown is the 00 hour forecast for 12 UTC, the available model time closest to the actual time of the event (11:30-11:45 UTC). Note curved jet exit and jet streak exit positioned over Southern California. 


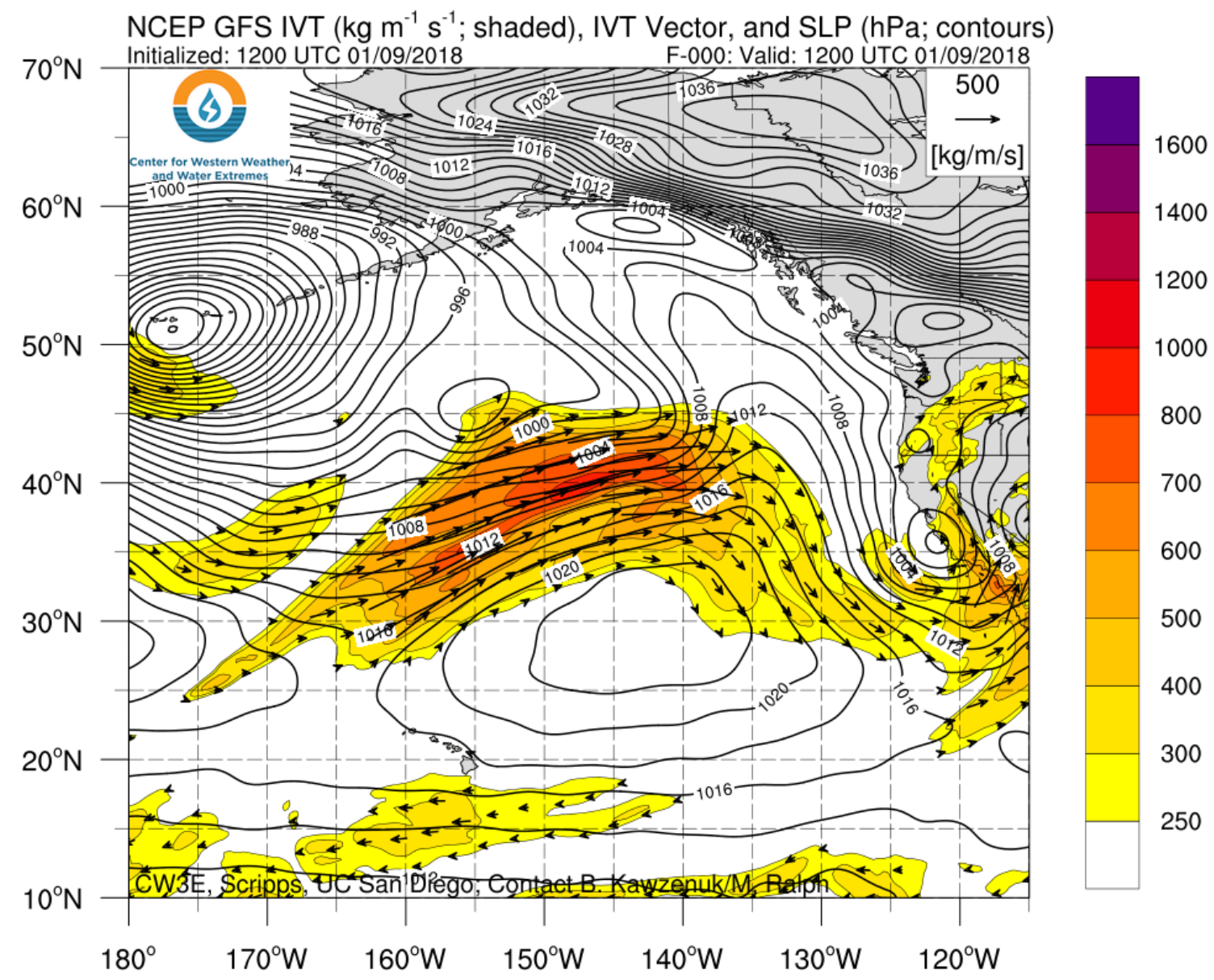

Figure S4: Integrated water vapor transport (IVT) from the National Centers for Environmental Prediction Global Forecast System. The time step shown is the 00 hour forecast for 12 UTC, the available model time closest to the actual time of the event (11:30-11:45 UTC). IVT of approximately $400 \mathrm{~kg} \mathrm{~m}^{-1} \mathrm{~s}^{-1}$ is observed in the vicinity of Southern California. 


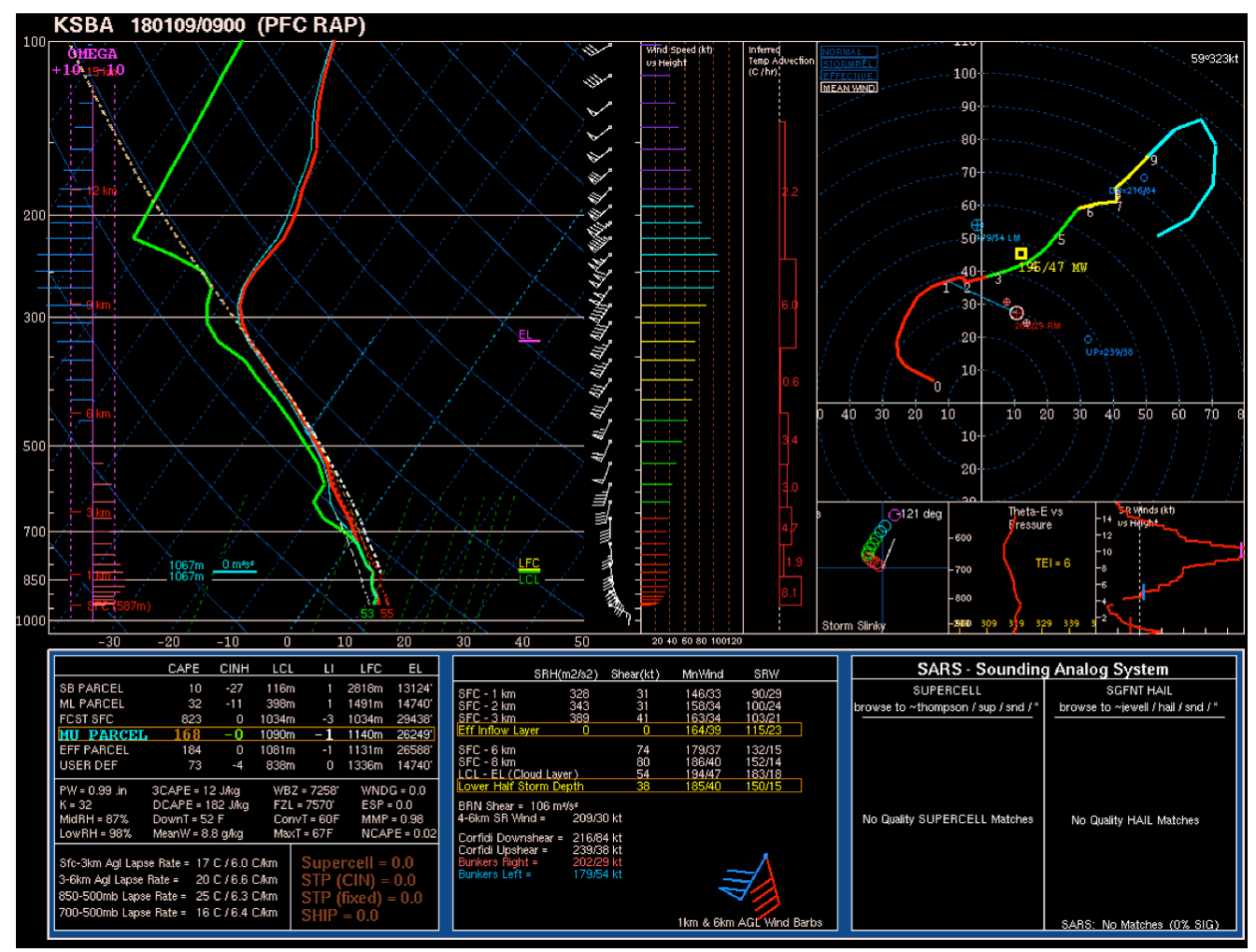

Figure S5: Sounding from the Rapid Refresh model (RAP;

http://rapidrefresh.noaa.gov) for Santa Barbara Airport (KSBA) at 9:00 UTC 9 January, the closest timestep preceding the PFDF event. Most unstable parcel CAPE is $168 \mathrm{~J} \mathrm{~kg}^{-1}$, and mixed layer CAPE is $32 \mathrm{~J} \mathrm{~kg}^{-1}$ Obtained from National Severe Storms Lab. 


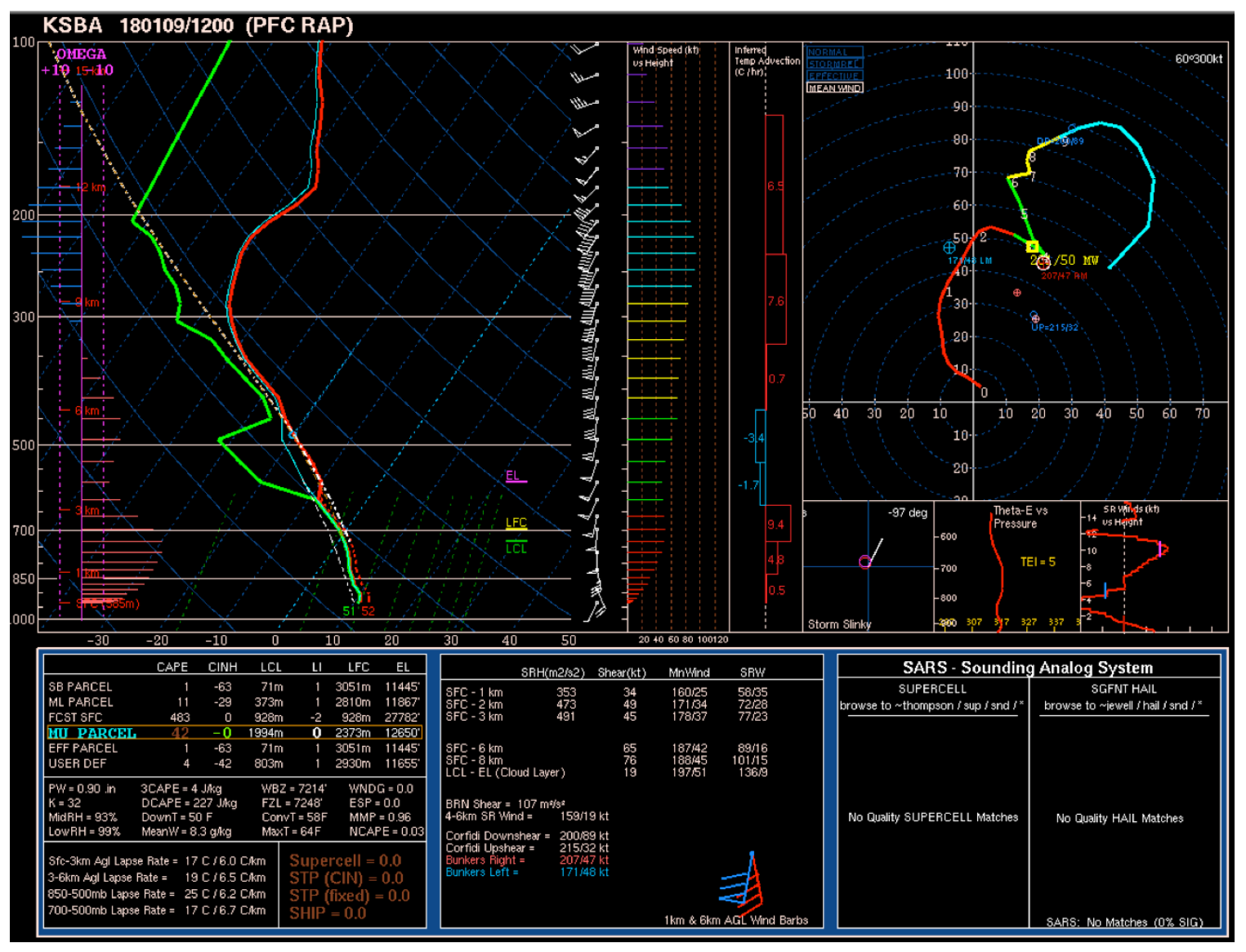

Figure S6: Sounding from the Rapid Refresh model (RAP; http://rapidrefresh.noaa.gov) for Santa Barbara Airport (KSBA) at 12:00 UTC 9 January, the closest timestep following the PFDF event. Most unstable parcel CAPE is $42 \mathrm{~J} \mathrm{~kg}^{-1}$, and mixed layer CAPE is $11 \mathrm{~J} \mathrm{~kg}^{-1}$. Obtained from National Severe Storms Lab. 

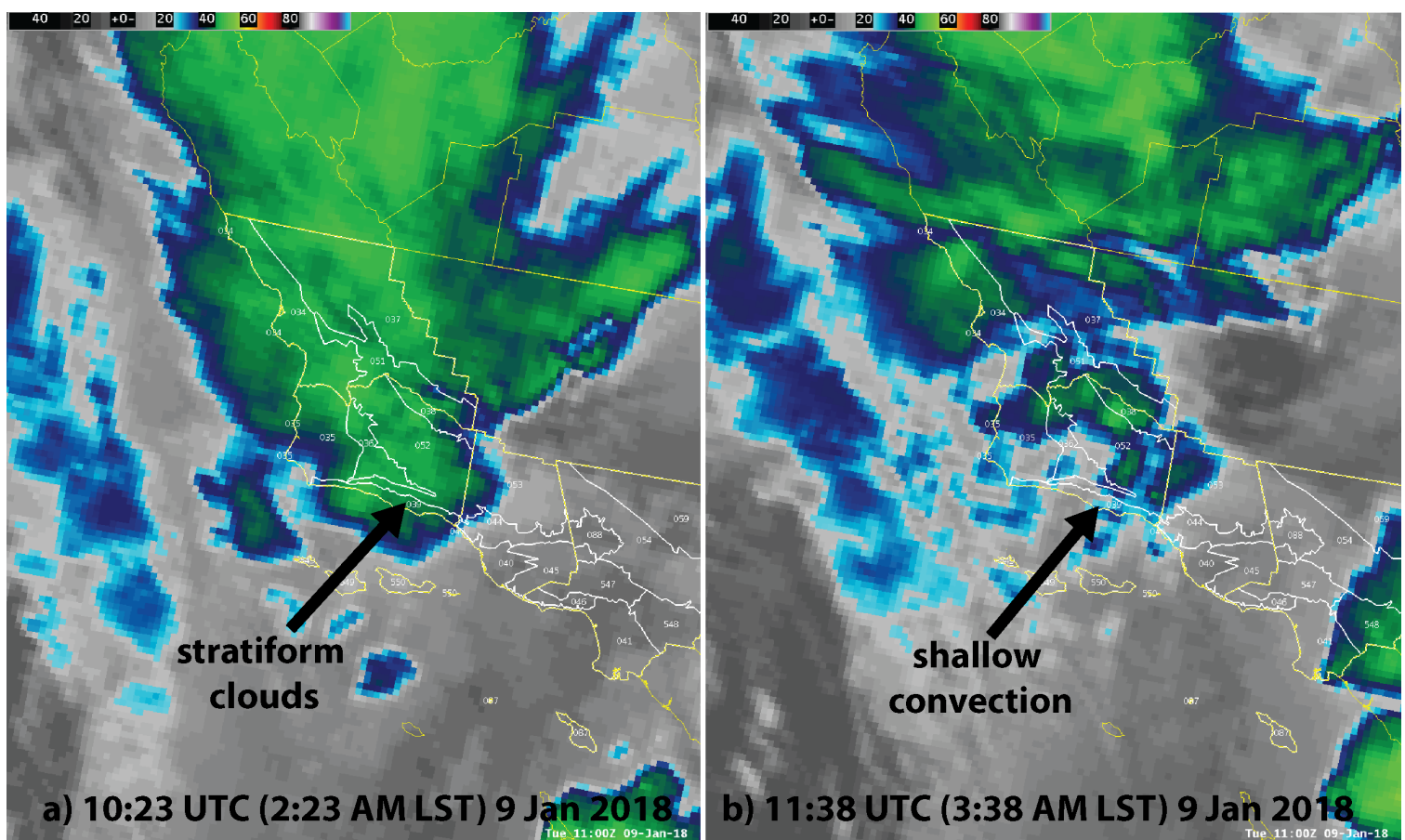

Figure S7: Satellite imagery from GOES East of southern California showing cloud top temperature in degrees Celsius. Prior to the event (a), stratiform precipitation processes were dominant as indicated by stratiform clouds. Near the time of the event (b), convective precipitation processes dominated as indicated by convective cumuliform clouds. The arrow points to the vicinity of Montecito and Carpinteria. 


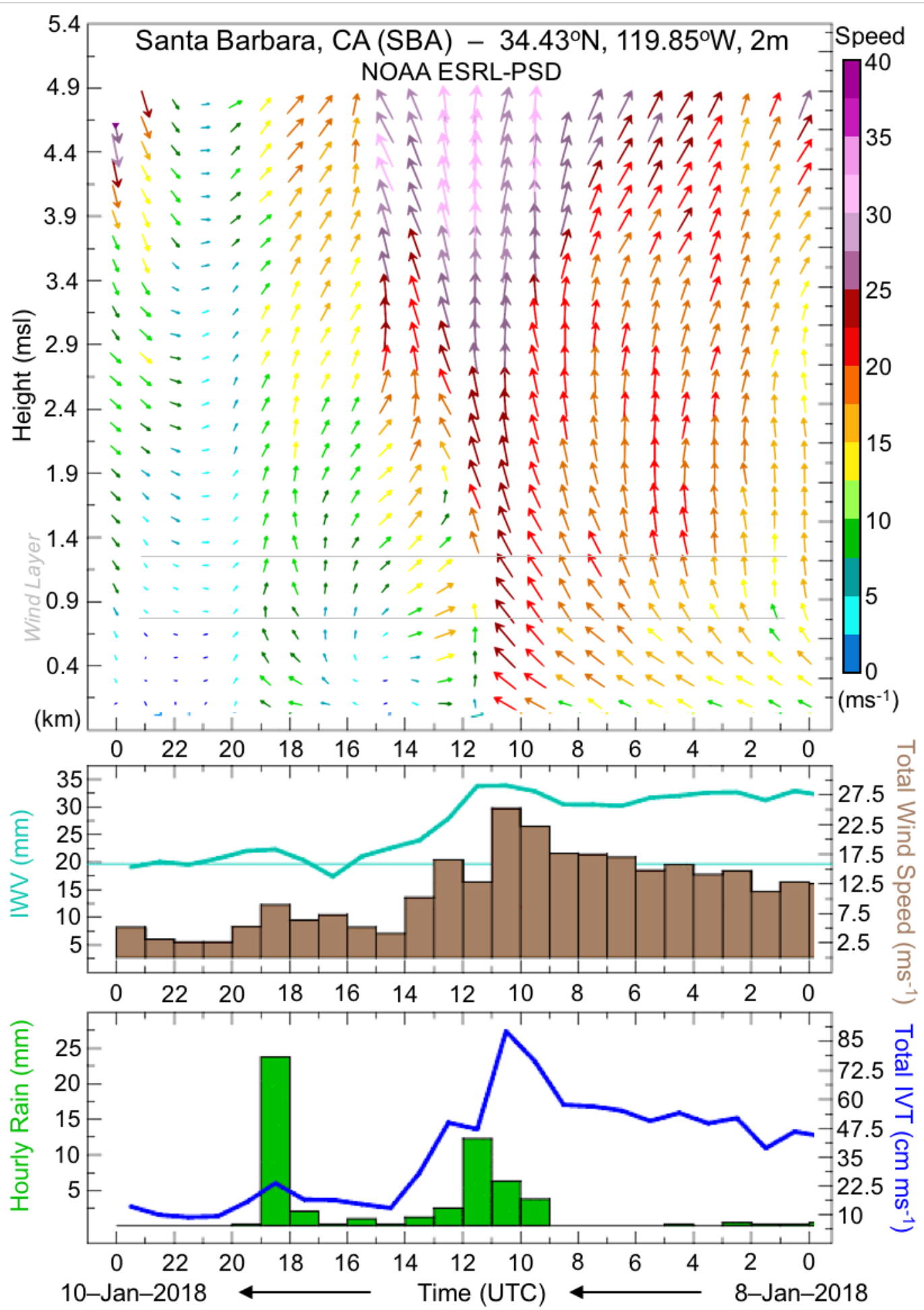

Figure S8: Observations from the 449 MHZ profiler at Santa Barbara Airport (KSBA; approximately $20 \mathrm{~km}$ west of Montecito) from 00 UTC 8 January to 00 UTC 10 January. Time moves from right to left. The top frame shows the vertical wind profile. The frontal passage at this location occurs between 10 and 12 UTC where there is a marked shift in low level wind speed and direction. The middle panel 
shows total wind speed as brown bars and integrated water vapor (IWV) as teal line. The bottom frame shows hourly precipitation at KSBA as green bars and total integrated water vapor transport (IVT) as blue line. Note peak in IVT between 10 and 12 UTC and subsequent rapid decline. Due to the fragmented nature of the narrow cold frontal rainband, the feature did not impact KSBA with as high intensity precipitation as was observed in the vicinity of Montecito.

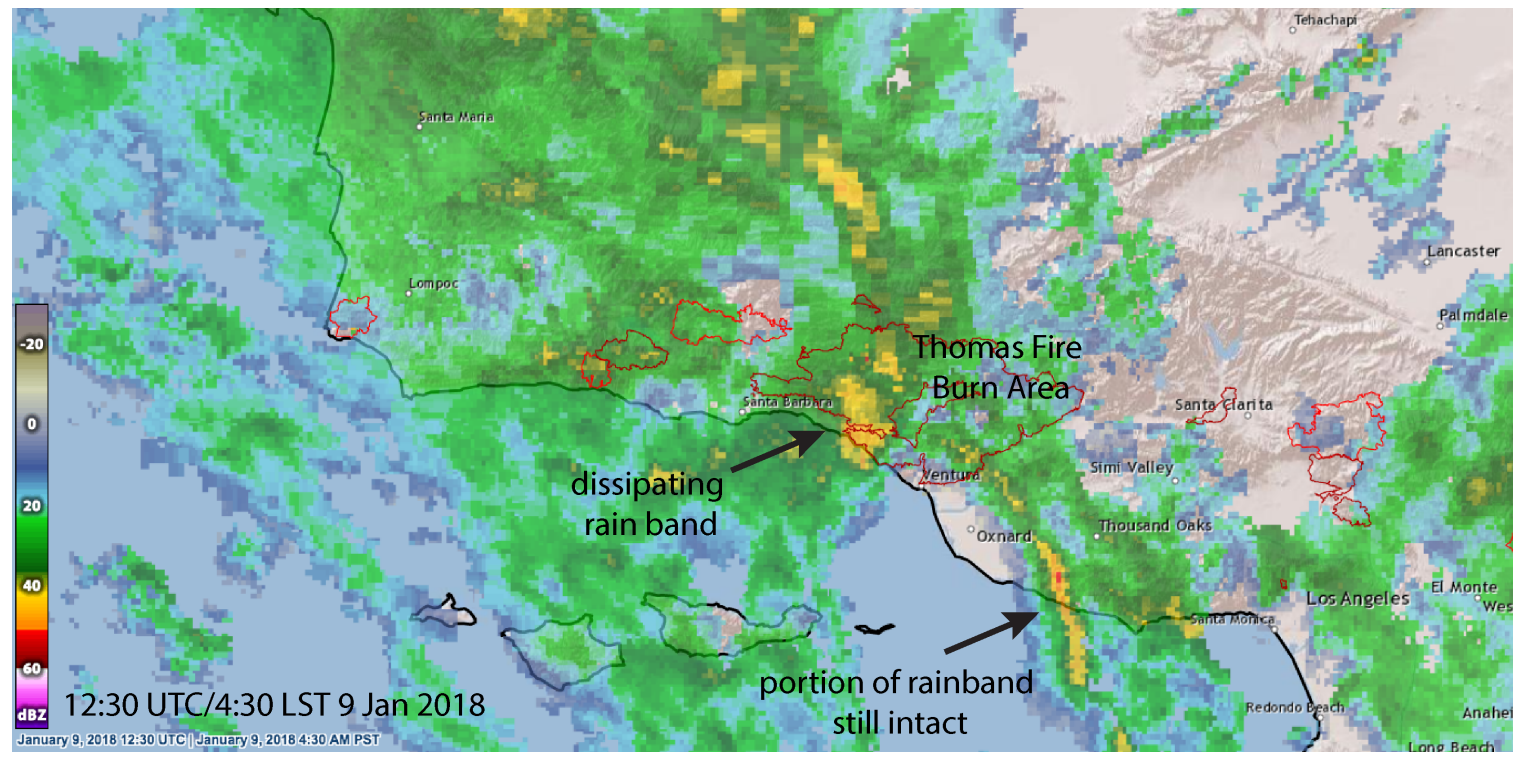

Figure S9: Radar imagery showing the narrow cold frontal rainband began to dissipate over the central portion of the Thomas Fire burn area around 4:30 LST 9 January 2018. A portion rainband along the cold front moved across the Oxnard Plain intact. Burn areas shown are from 2016 and 2017.

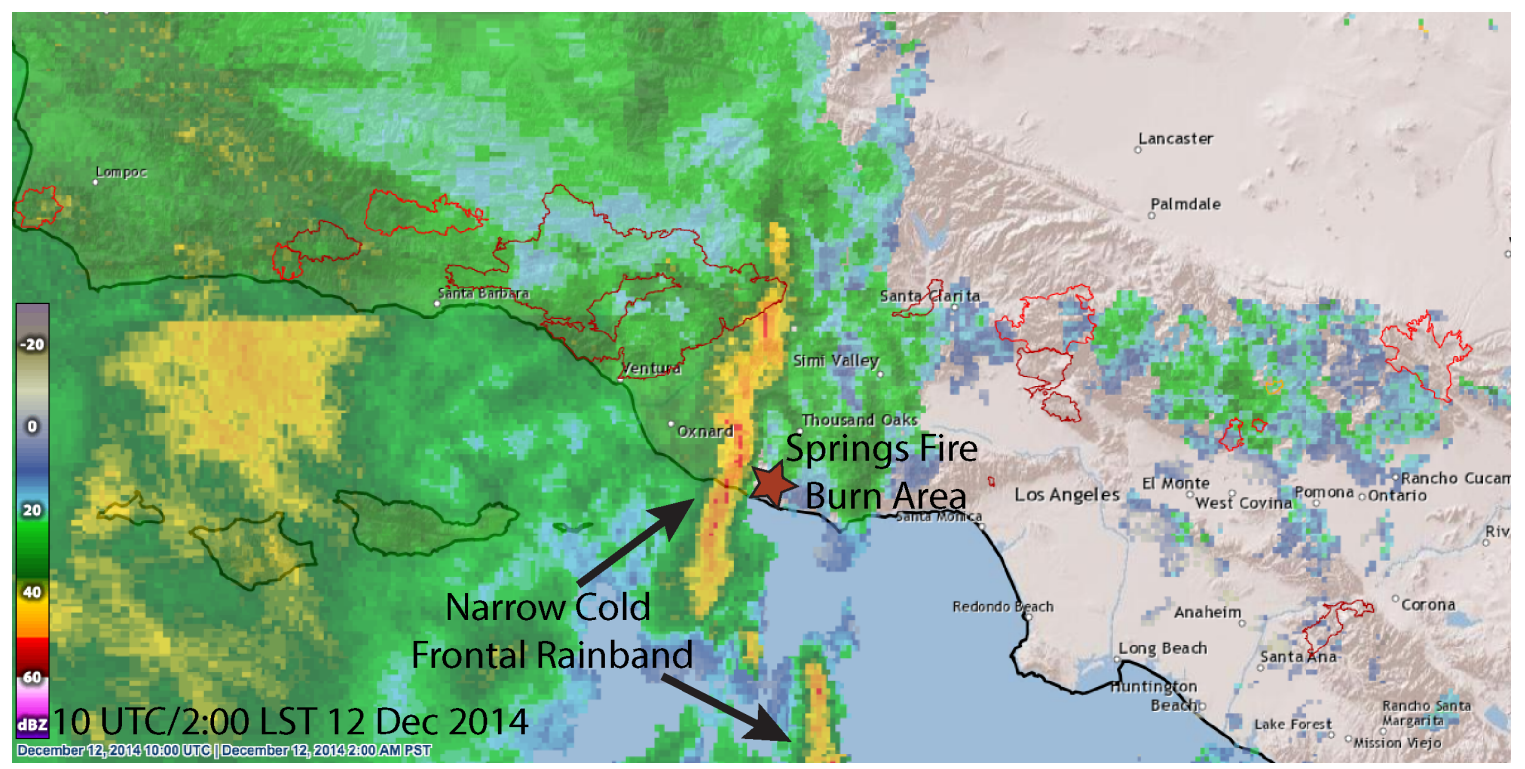

Figure S10: Radar imagery showing a narrow cold frontal rainband impacting the Springs Fire burn area in Camarillo Springs on 12 December 2014. The burn areas 
outlined in the figure are from 2016 and 2017; the Springs Fire perimeter is not shown but location is represented with a red star.

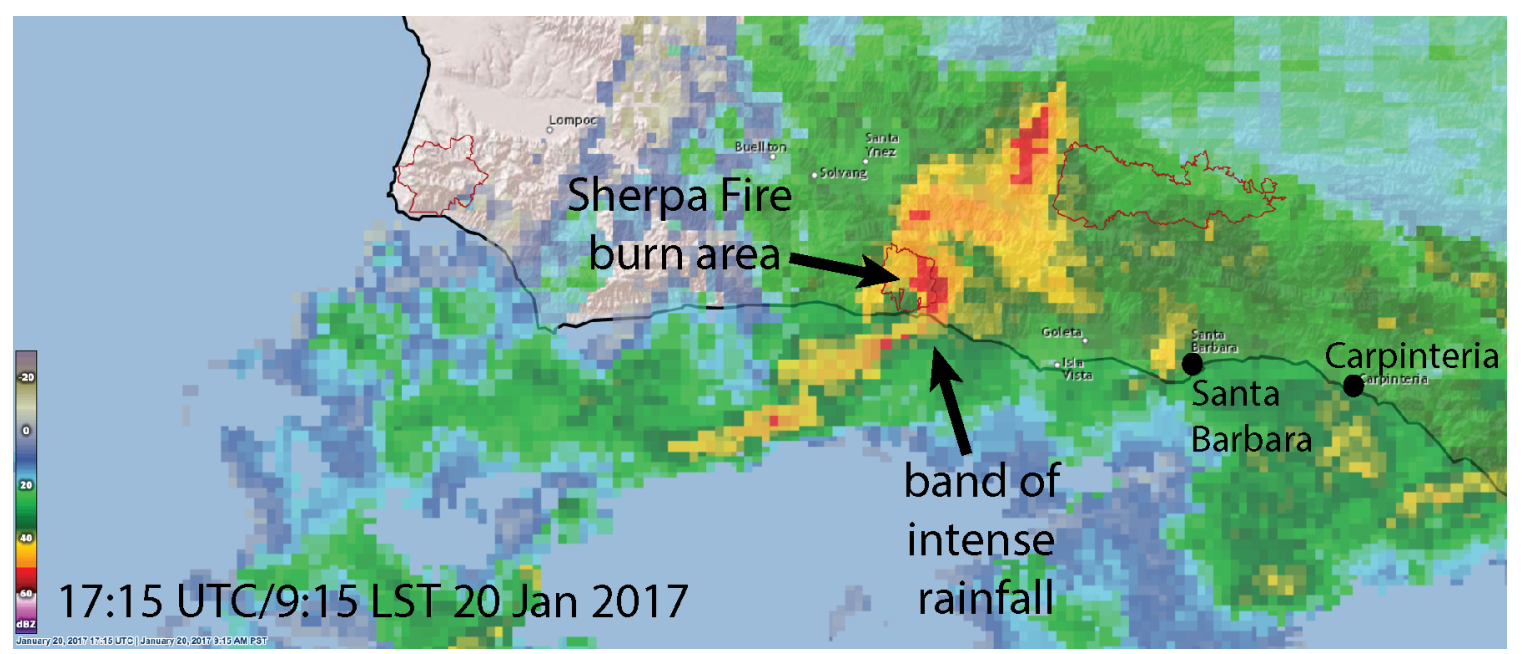

Figure S11: Radar imagery showing a band of intense precipitation impacting the Sherpa Fire burn area on 20 January 2017. The burn areas outlined in the figure are from 2016.

\begin{tabular}{|c|c|c|c|c|c|}
\hline 1 & 2 & 3 & 4 & 5 & 6 \\
\hline Station & $\begin{array}{l}\text { Elev. } \\
\text { (ft) }\end{array}$ & $\begin{array}{l}9 \text { Jan } \\
2018 \text { Event } \\
5 \text { min max } \\
\text { (in) }\end{array}$ & $\begin{array}{l}\text { Recurrence } \\
\text { Interval of } \\
\mathbf{9} \text { Jan } \mathbf{2 0 1 8} \\
\mathbf{5} \mathbf{m i n} \text { max } \\
\text { from NOAA } \\
\text { Atlas } 14\end{array}$ & $\begin{array}{l}\text { Station } \\
\text { record } \\
5 \text { min obs. } \\
\text { (in) }\end{array}$ & $\begin{array}{l}\text { Period } \\
\text { considered } \\
\text { for station } \\
\text { record }\end{array}$ \\
\hline Stanwood FS & 670 & $\begin{array}{l}10.67 \mathrm{~mm} \\
0.42 \mathrm{in}\end{array}$ & $\begin{array}{l}50 \text { Year } \\
(25-200)\end{array}$ & $\begin{array}{l}13.21 \mathrm{~mm} \\
0.52 \mathrm{in} \\
(2014 / 15)\end{array}$ & 1953-2017 \\
\hline El Deseo & 3300 & $\begin{array}{l}11.68 \mathrm{~mm} \\
0.46 \mathrm{in}\end{array}$ & $\begin{array}{l}25 \text { Year } \\
(10-50)\end{array}$ & $\begin{array}{l}12.45 \mathrm{~mm} \\
0.49 \mathrm{in} \\
(2004 / 05)\end{array}$ & 1969-2017 \\
\hline $\begin{array}{l}\text { Doulton } \\
\text { Tunnel }\end{array}$ & 1775 & $\begin{array}{l}15.24 \mathrm{~mm} \\
0.60 \mathrm{in}\end{array}$ & $\begin{array}{l}100 \text { Year } \\
(25-1000)\end{array}$ & $\begin{array}{l}12.7 \mathrm{~mm} \\
0.50 \mathrm{in} \\
(2014 / 15)\end{array}$ & $1965-2017$ \\
\hline $\begin{array}{l}\text { Jameson } \\
\text { Dam }\end{array}$ & 2230 & $\begin{array}{l}15.24 \mathrm{~mm} \\
0.60 \mathrm{in}\end{array}$ & $\begin{array}{l}25 \text { Year } \\
(25-1000)\end{array}$ & $\begin{array}{l}13.46 \mathrm{~mm} \\
0.53 \mathrm{in} \\
(1997 / 98)\end{array}$ & $1965-2017$ \\
\hline Edison Trail & 1650 & $\begin{array}{l}8.89 \mathrm{~mm} \\
0.35 \mathrm{in}\end{array}$ & $\begin{array}{l}5 \text { Year } \\
(5-10)\end{array}$ & $\begin{array}{l}12.45 \mathrm{~mm} \\
0.49 \mathrm{in} \\
(2004 / 05)\end{array}$ & $\begin{array}{l}1993-2017 \\
\text { *short length }\end{array}$ \\
\hline Carpinteria & 32 & $9.14 \mathrm{~mm}$ & 10 Year & $9.14 \mathrm{~mm}$ & 1964-2017 \\
\hline
\end{tabular}




\begin{tabular}{|l|l|l|l|l|l|}
\hline FS & & 0.36 in & $(10-25)$ & $\begin{array}{l}0.36 \text { in } \\
(1968 / 69)\end{array}$ & \\
\hline Montecito & 150 & $\begin{array}{l}13.72 ~ \mathbf{~ m m} \\
0.54 \text { in }\end{array}$ & $\begin{array}{l}200 \text { Year } \\
(100-1000)\end{array}$ & $\begin{array}{l}7.62 \mathrm{~mm} \\
0.3 \mathrm{in} \\
(2009 / 10)\end{array}$ & $\begin{array}{l}2009-2017 \\
{ }^{*} \text { short length }\end{array}$ \\
\hline
\end{tabular}

Table S1: Columns 1-5 provide data from Santa Barbara County Public Works Department's (SBCPWD) rain gauge network. Columns 1 and 2 provide the station name and elevation. Column 3 provides the 5 -minute maximum precipitation value observed during the 9 January 2018 debris flow. Values that set new records for the station are given in bold. Column 4 gives the average recurrence interval extracted from NOAA Atlas 14 based on the latitude and longitude of each station. The number in parentheses in this column indicates the span of average recurrence intervals that contain the 9 Jan 2018 observed value in their $90 \%$ confidence interval. Column 5 provides the 5-minute precipitation record for that station prior to the 9 Jan 2018 event and the Water Year (September-August) in which it occurred in parentheses. Column 6 describes the length of the station record used to determine the values in column 5 . Note the relatively short records ( $<30$ years) for Edison Trail and Montecito. Station records are available from SBCPWD at http://www.countyofsb.org/pwd/rainintensity.sbc.

\begin{tabular}{|c|c|c|c|c|c|}
\hline 1 & 2 & 3 & 4 & 5 & 6 \\
\hline Station & $\begin{array}{l}\text { Elev. } \\
\text { (ft) }\end{array}$ & $\begin{array}{l}9 \text { Jan } \\
2018 \text { Event } \\
15 \text { min } \\
\text { max }\end{array}$ & $\begin{array}{l}\text { Recurrence } \\
\text { Interval of } \\
\mathbf{9} \text { Jan } 2018 \\
\mathbf{1 5} \text { min max } \\
\text { from NOAA } \\
\text { Atlas } 14\end{array}$ & $\begin{array}{l}\text { Station } \\
\text { record } \\
15 \text { min obs. }\end{array}$ & $\begin{array}{l}\text { Period } \\
\text { considered } \\
\text { for station } \\
\text { record }\end{array}$ \\
\hline Stanwood FS & 670 & $\begin{array}{l}13.97 \mathrm{~mm} \\
0.55 \mathrm{in}\end{array}$ & $\begin{array}{l}10 \text { Year } \\
(10-25)\end{array}$ & $\begin{array}{l}30.23 \mathrm{~mm} \\
1.19 \mathrm{in} \\
(1983 / 84)\end{array}$ & $1953-2017$ \\
\hline El Deseo & 3300 & $\begin{array}{l}16.26 \mathrm{~mm} \\
0.64 \mathrm{in}\end{array}$ & $\begin{array}{l}5 \text { Year } \\
(5-10)\end{array}$ & $\begin{array}{l}23.11 \mathrm{~mm} \\
0.91 \mathrm{in} \\
(2004 / 05)\end{array}$ & $1969-2017$ \\
\hline $\begin{array}{l}\text { Doulton } \\
\text { Tunnel }\end{array}$ & 1775 & $\begin{array}{l}26.16 \mathbf{~ m m} \\
1.03 \mathrm{in}\end{array}$ & $\begin{array}{l}100 \text { Year } \\
(25-1000)\end{array}$ & $\begin{array}{l}22.35 \mathrm{~mm} \\
0.88 \mathrm{in} \\
(2014 / 15)\end{array}$ & $1965-2017$ \\
\hline $\begin{array}{l}\text { Jameson } \\
\text { Dam }\end{array}$ & 2230 & $\begin{array}{l}25.15 \mathbf{~ m m} \\
0.99 \mathrm{in}\end{array}$ & $\begin{array}{l}25 \text { Year } \\
(10-500)\end{array}$ & $\begin{array}{l}24.38 \mathrm{~mm} \\
0.96 \mathrm{in} \\
(1997 / 98)\end{array}$ & $1965-2017$ \\
\hline Edison Trail & 1650 & $\begin{array}{l}19.81 \mathrm{~mm} \\
0.78 \mathrm{in}\end{array}$ & $\begin{array}{l}25 \text { Year } \\
(10-50)\end{array}$ & $\begin{array}{l}23.11 \mathrm{~mm} \\
0.91 \mathrm{in} \\
(2004 / 05)\end{array}$ & $\begin{array}{l}1993-2017 \\
\text { *short length }^{2}\end{array}$ \\
\hline $\begin{array}{l}\text { Carpinteria } \\
\text { FS }\end{array}$ & 32 & $\begin{array}{l}\mathbf{2 1 . 8 4} \mathbf{~ m m} \\
0.86 \mathrm{in}\end{array}$ & $\begin{array}{l}50 \text { Year } \\
(25-1000)\end{array}$ & $\begin{array}{l}16.76 \mathrm{~mm} \\
0.66 \mathrm{in}\end{array}$ & 1964-2017 \\
\hline
\end{tabular}




\begin{tabular}{|l|l|l|l|l|l|}
\hline & & & & $(1974 / 75)$ & \\
\hline Montecito & 150 & $\begin{array}{l}\mathbf{1 8 . 5 4} \mathbf{~ m m} \\
0.73 \text { in }\end{array}$ & $\begin{array}{l}50 \text { Year } \\
(25-1000)\end{array}$ & $\begin{array}{l}10.67 \mathrm{~mm} \\
0.42 \text { in } \\
(2015 / 16)\end{array}$ & $\begin{array}{l}\text { *009-2017 } \\
\end{array}$ \\
& & & \\
\hline
\end{tabular}

Table S2: As in Table 1 for 15-minute precipitation records.

\begin{tabular}{|c|c|c|c|c|c|}
\hline 1 & 2 & 3 & 4 & 5 & 6 \\
\hline Station & $\begin{array}{l}\text { Elev. } \\
\text { (ft) }\end{array}$ & $\begin{array}{l}9 \text { Jan } \\
2018 \text { Event } \\
1 \mathrm{~h} \max \\
\text { (in) }\end{array}$ & $\begin{array}{l}\text { Recurrence } \\
\text { Interval of } \\
\mathbf{9} \text { Jan } 2018 \\
\mathbf{1 h} \text { max } \\
\text { from } N O A A \\
\text { Atlas } 14\end{array}$ & $\begin{array}{l}\text { Station } \\
\text { record } \\
\text { 1h obs. (in) }\end{array}$ & $\begin{array}{l}\text { Period } \\
\text { considered } \\
\text { for station } \\
\text { record }\end{array}$ \\
\hline Stanwood FS & 670 & $\begin{array}{l}17.27 \mathrm{~mm} \\
0.68 \mathrm{in}\end{array}$ & 1 Year & $\begin{array}{l}60.96 \mathrm{~mm} \\
2.40 \mathrm{in} \\
(1983-84)\end{array}$ & $1953-2017$ \\
\hline El Deseo & 3300 & $\begin{array}{l}24.38 \mathrm{~mm} \\
0.96 \mathrm{in}\end{array}$ & 1 Year & $\begin{array}{l}47.24 \mathrm{~mm} \\
1.86 \mathrm{in} \\
(2004-05)\end{array}$ & $1969-2017$ \\
\hline $\begin{array}{l}\text { Doulton } \\
\text { Tunnel }\end{array}$ & 1775 & $\begin{array}{l}39.12 \mathrm{~mm} \\
1.54 \mathrm{in}\end{array}$ & $\begin{array}{l}10 \text { Year } \\
(5-25)\end{array}$ & $\begin{array}{l}57.15 \mathrm{~mm} \\
2.25 \mathrm{in} \\
(1972-73)\end{array}$ & $1965-2017$ \\
\hline $\begin{array}{l}\text { Jameson } \\
\text { Dam }\end{array}$ & 2230 & $\begin{array}{l}37.85 \mathrm{~mm} \\
1.49 \mathrm{in}\end{array}$ & 5 Year & $\begin{array}{l}55.88 \mathrm{~mm} \\
2.20 \mathrm{in} \\
(1965-66)\end{array}$ & $1965-2017$ \\
\hline Edison Trail & 1650 & $\begin{array}{l}36.83 \mathrm{~mm} \\
1.45 \mathrm{in}\end{array}$ & $\begin{array}{l}10 \text { Year } \\
(5-10)\end{array}$ & $\begin{array}{l}40.13 \mathrm{~mm} \\
1.58 \mathrm{in} \\
(1994-95)\end{array}$ & $\begin{array}{l}\text { 1993-2017 } \\
\text { *short length }\end{array}$ \\
\hline $\begin{array}{l}\text { Carpinteria } \\
\text { FS }\end{array}$ & 32 & $\begin{array}{l}35.05 \mathrm{~mm} \\
1.38 \mathrm{in}\end{array}$ & $\begin{array}{l}25 \text { Year } \\
(10-50)\end{array}$ & $\begin{array}{l}42.93 \mathrm{~mm} \\
1.69 \mathrm{in} \\
(1994-95)\end{array}$ & $1964-2017$ \\
\hline Montecito & 150 & $\begin{array}{l}24.13 \mathbf{~ m m} \\
0.95 \mathrm{in}\end{array}$ & $\begin{array}{l}5 \text { Year } \\
(2-5)\end{array}$ & $\begin{array}{l}20.57 \mathrm{~mm} \\
0.81 \mathrm{in} \\
(2015 / 16)\end{array}$ & $\begin{array}{l}2009-2017 \\
\text { *short length }\end{array}$ \\
\hline
\end{tabular}

Table S3: As in Table 1 for $1 \mathrm{~h}$ precipitation records. 